\title{
RAINWATER FOR DRINKING WATER: A STUDY OF HOUSEHOLD ATTITUDES
}

\author{
CHIRHAKARHULA E. CHUBAKA, KIRSTIN E. ROSS \& JOHN W. EDWARDS \\ School of the Environment, Flinders University, Australia
}

\begin{abstract}
Many people in Australia choose to drink rainwater, even in areas where clean municipal water is available. Domestic rainwater is defined here as any water collected from building rooftops subsequent to rainfall events and stored by households for later use. Rainwater has been found in some cases to contain bacteria, or trace metals, or both. As a result, in Australia, the Department of Health and Ageing advises the public to limit rainwater use to outdoor purposes, and to laundry and toilet flushing. In this study, over 12 months, rainwater samples were collected around Adelaide and tested for E. coli and total coliforms. Of 400 samples tested, more than $50 \%$ contained E. coli. In Australia, the health guideline for $E$. coli is $0 / 100 \mathrm{~mL}$ for drinking water. A survey on household drinking water choice was undertaken across the metropolitan area of Adelaide. The aim was to determine drinking water choices and to understand the driving forces behind drinking potentially contaminated rainwater in a city where clean municipal water is supplied. The investigation concluded that a higher proportion of households use rainwater as their primary source of drinking water in the Adelaide Hills and foothills compared with other areas in metropolitan Adelaide (the Adelaide plains). It was found that a higher proportion of households are using domestic filtration systems to improve municipal water quality in the Adelaide plains. Opposition to municipal water chlorination and fluoridation was reported and this was central to peoples' drinking water preferences. Notably, this opposition to municipal water chlorination and fluoridation is not supported by epidemiological evidence suggesting that these chemicals are harmful. Keywords: public perception, drinking water, E. coli, household, fluoride, chlorination.
\end{abstract}

\section{INTRODUCTION}

The supply of safe and adequate drinking water to communities remains a global challenge [1], and water security is an important issue for many communities [2]. Water security is not only the absence of water, but also water quality, particularly with respect to water-borne diseases [2]. In Australian cities, water utilities supply high quality, safe reticulated municipal water, but many Australians are preferentially drinking roof harvested rainwater (RHRW). This observed behaviour and the underlying factors giving rise to this choice is the focal point of this investigation.

In many areas of Australia, concerns over water security arise from water quality rather than quantity of water supplies, and many small towns in regional and remote Australia still have limited access to clean water. Notwithstanding, in Australia, threats to water security include drought conditions and population growth. Projections indicate a doubling demand in water resources for Australia by 2050 [3]. Following drought conditions, water storage was severely reduced in Victoria, with Melbourne water storage declining by 152 GL in 2015 [4]. In South Australia, the raw water prior to treatment is often of poor quality. This means that the level of treatment necessary can be extensive [5]. Additionally, water quality and quantity are impacted by population growth and extreme weather conditions. In New South Wales and Tasmania, notices of water boiling are periodically issued to the public and in 2016, 18 Tasmanian water utilities were targeted by notices of water boiling. In that same year, 23 drinking water alerts were issued by NSW Health [6]. In many areas of NSW, water hardness is the primary contributor to poor municipal water quality [7]. For example, in the 
regional towns of Quirindi, Walhallow and Caroona, it's common to hear local people claiming that there is no water to drink despite municipal water being supplied, if rainwater is unavailable [8]. Further west, since 2000, concerns over municipal water quality emerged in 26 towns in the mid-west and goldfields regions of Western Australia [9].

Incentives to address these challenges are underway in Australia and include increased funding, regulatory frameworks, quality control and community engagement [10], and water recycling, seawater desalination and RHRW are emerging as options with the potential to mitigate water stress.

RHRW can be associated with bacteria and metals that may be harmful to humans' health [11]. Many Australians use RHRW as their primary source of drinking water [12]. The EPA Victoria [13], echoing the Department of Health and Ageing (DHA) messages [14], advises the public to abstain from drinking RHRW in areas where municipal water is accessible. South Australia and its capital city Adelaide have higher proportion of households drinking RHRW compared with the rest of Australia [15]. Enteric E. coli, total coliforms and trace metals have been detected in RHRW in Adelaide [16]. The health guideline for E. coli is 0 CFU/100 $\mathrm{mL}$ in drinking water [16].

A study by de França Doria [17] found that taste, smell and physical appearance are central to community perception of municipal water quality. If smell, taste or colour can be perceived, the water is considered to be of poorer quality. This is despite the fact that, with the exception of manganese (concentration $\geq 0.5 \mathrm{ppm} / \mathrm{L}$ ) and sulphate (concentration $\geq$ $500 \mathrm{ppm} / \mathrm{L}$ ), bacteria and dissolved metals are unlikely to affect drinking water taste [18]. Detection of poor water quality requires expertise and appropriate laboratory tests. The bacteria and metals that can affect water quality are not visible and contaminated water can feature all the qualities of clean water [19].

Concerns over municipal water quality, consumers' lifestyle factors, and the absence of municipal water supplies are the primary factors contributing to drinking RHRW [20]. In Australia, water supplied to communities is disinfected as precautionary measure to reduce risks and as the final barrier to prevent water borne pathogenic bacteria from entering the distribution network [21]. Chlorine $(\mathrm{NaCl})$, potassium chloride $(\mathrm{KCl})$, citric acid $\left(\mathrm{C}_{6} \mathrm{H}_{8} \mathrm{O}_{7}\right)$ and chlorine dioxide $\left(\mathrm{ClO}_{2}\right)$ are largely used in drinking water disinfection [16]. Whilst not directly part to the treatment process, fluoride $(\mathrm{F})$ is introduced in municipal water to prevent dental caries in children. In Australia, commonly used fluoride components include sodium fluoride $(\mathrm{NaF})$, sodium fluorosilicate $\left(\mathrm{Na}_{2} \mathrm{SiF}_{6}\right)$ and aqueous fluorosilicic acid $\left(\mathrm{H}_{2} \mathrm{SiF}_{2}\right)$ [22]

Drinking water fluoridation is accepted practice by the Australian health authorities (NHMRC [16]), and a drinking water fluoridation policy controlled and implemented by States and Territories is enforced in Australia (16)]. The NHMRC [16] sets the guideline for fluoride in drinking water at $1.5 \mathrm{ppm} / \mathrm{L}$. In Adelaide, the average guideline for fluoride in drinking water is $0.88 \mathrm{ppm} / \mathrm{L}$ [23]. Despite the significant achievement of dental caries prevention in children resulting from fluoride and improved water sanitation resulting from chlorine, debate still exists around the introduction of chlorine and fluoride in drinking water.

Studies by Cantor [24], Hassinger and Watson [25], and Plewa et al. [26] indicate that chlorine in drinking water has the potential to bladder, stomach, pancreas, kidney, and rectum cancer, and Hodgkin's and non-Hodgkin's lymphoma. However, it is not clear whether the concentrations of chlorine currently added to drinking water could trigger an incident of illness. Studies have shown that fluoride in drinking water could result in bone fractures in children at $3 \mathrm{ppm} / \mathrm{L}$ and in hip fractures in elderly from $1.5 \mathrm{ppm} / \mathrm{L}$ to $4.3 \mathrm{ppm} / \mathrm{L}$ [27], [28], in lowering children IQ from $2.47 \mathrm{ppm} / \mathrm{L}$ to $4.5 \mathrm{ppm} / \mathrm{L}$ [26], in lowering fertility at $3.0 \mathrm{ppm} / \mathrm{L}$ and in thyroid dysfunction at $2.3 \mathrm{ppm} / \mathrm{L}$ [27], [29]. Notwithstanding, this is countered by a 
review of 33 studies, which concluded that fluoridated water at $1 \mathrm{ppm} / \mathrm{L}$ does not have an adverse effect on bone strength, bone mineral density and fracture incidence, and at higher concentrations may even have a favourable effect on these parameters [30].

\section{METHODS}

\subsection{Study area and design}

A survey of households' drinking water choice was conducted from March to May 2016 in five locations around the metropolitan area of Adelaide. Of five survey locations, two were located in the Adelaide plains, one in the Adelaide foothills and two in the Adelaide Hills (see Fig. 1). Interviews were run in car parks adjacent to shopping malls during the busiest times, from 9:00 am to 3:00 pm. At times, interviews were conducted on Saturdays and Sundays to maximise the chance of including working people in the survey. An application to allow the access to survey sites and a certificate of public liability (Certificate No.: UL FLI 16) were sent to the management of shopping malls to comply with the provision of SA Trespass Act 1953 which regulates entries on private properties [31]. In Adelaide, most shopping malls are owned privately. On approval, a reply mail to allow the access to the study area was sent by electronic mail. In event of late response or response not received, officers in shopping malls were directly contacted to obtain the approval. A number of shopping malls refused to allow access on their properties for undisclosed reasons.

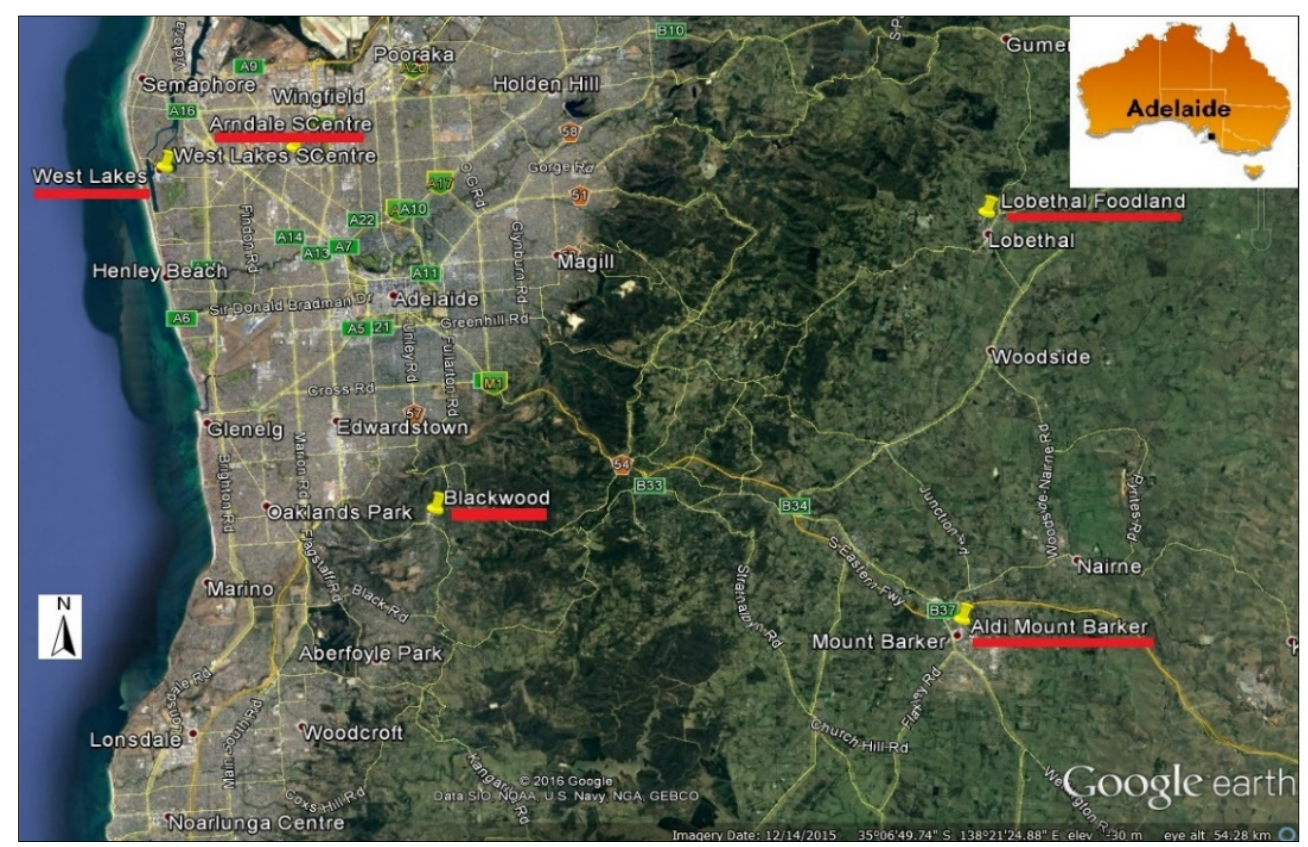

Figure 1: Study area map, Adelaide, South Australia. 
The study was approved by Flinders University Social and Behavioural Research Ethics Committee (SBREC No. 6782) in compliance with the National Statement on Ethical Conduct in Human Research (NSECHR) [32]. The survey used the National Statistical Service (NSS) sample calculator to determine the sample size, using $95 \%$ as confidence level (CL), 0.5 as proportion, 0.05 as confidence interval (CI) and 5.11 as relative standard error (RSE) [33]. The survey involved 459 respondents. The sample was representative of an estimate 504.400 households identified in Adelaide in 2011 [34]. Participants were randomly chosen among people entering or leaving shopping malls and answering questions was voluntary. The survey was anonymous. The chi-square $\left(\mathrm{X}^{2}\right)$ statistic model was used in testing parameters goodness-of-fit. This is expressed in the test statistic equation (eqn 1):

$$
X^{2}=\sum \frac{(O-E)^{2}}{E}
$$

where: $X^{2}=$ Chi-square, $E=$ expected frequency, $O=$ observed frequency.

\subsection{Questionnaire construction and design}

Five questions were put to persons aged 18 and over, and questions included suggested responses as prompts and allowed free responses where desired.

- Which water do you most drink? Answers included town water or municipal water, bottle water and RHRW.

- Why do you prefer drinking municipal water, bottle water or RHRW? Proposed answers included: it's more convenient, it's clean water and it tastes better.

- Do you have any other reasons for choosing municipal water, bottle water or RHRW? The question was purposely unprompted to allow respondents to expand on reasons in prolong to their drinking water choices. An additional question of 'How do you use your RHRW' was asked to respondents having RHRW harvesting systems but not using RHRW for drinking.

- Do you have a RHRW tank? Answers consisted in 'Yes' or 'No' without further option.

- What is your postcode? The question was used to identify participants' area to later establish their relative socio-economic status. In Australia, suburban postcodes align with the Australian socio-economic indexes for areas (SEIFA). In the survey, SEIFA indexes were based on data collected during 2011 census of population and housing [35]. The maximum time to answer the questionnaire was set to three minutes however; some respondents devoted more time to expand their views on drinking water quality.

\section{RESULTS AND DISCUSSION}

People's drinking water choices, in many ways, are based on municipal water community perception [36]. While studies exist on municipal water, groundwater and recycled water, limited resources were found on RHRW community perception, given recent government incentives to RHRW harvesting and use in Australia [37]. Studies by de França Doria [38] have concluded low health risks associated with drinking municipal water. A gap exists between perceived benefits and risks to encounter in making drinking water options [37], and the public is more inclined to understand the level of risks severity when they are directly perceptible and with immediate effects [39]. 
In two respects, the investigation provided insight into trends in RHRW harvesting and use in Adelaide. Firstly, the investigation showed the magnitude of RHRW consumption and related driving factors to consumption. Secondly, the investigation found relationships between RHRW consumers, their geographical distribution and associated relative socio-economic indexes. Survey responses were grouped into themes and tallied for examples.

\subsection{Source of drinking water}

Results of household drinking water sources are presented in Fig. 2. The investigation found that a higher proportion of households were using RHRW as their primary source of drinking water in the Adelaide Hills. The tendency was observed from the Adelaide foothills and gradually, reached higher proportions in the Adelaide Hills. The limited or absence of municipal water supplied to communities in many small towns of the Adelaide Hills makes RHRW the most convenient source of drinking water in the area. As a result, RHRW consumption was more popular than any other water in the Adelaide Hills. In contrast, RHRW was less popular in the Adelaide plains. In this area, drinking municipal water and bottled water dominated, with higher proportion of households drinking municipal water in western suburbs, and increasingly in the Adelaide foothills.

$P$-values of parameters tested in the model $(P<0.0001)$ were lower than the critical statistic value of 0.05 (see Table 1). This suggested a correlation that could exist between households and the source of their drinking water. In the model, the proportion of respondents who indicated drinking municipal water, along with those who drink RHRW, was central to the chi-square formation. Locations such as Lobethal and West Lakes had larger chi-square statistic values; indicating greater likelihood of linking households' choices and the sources of their drinking water.

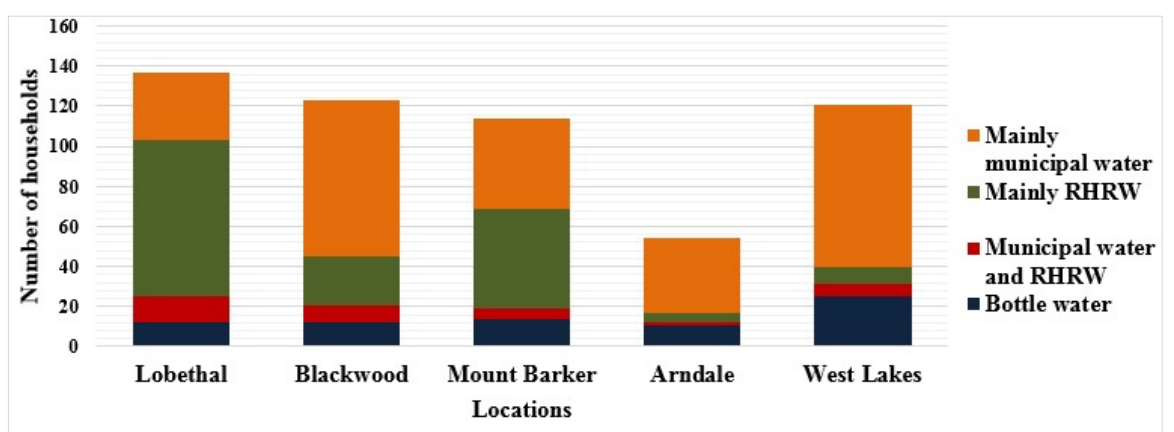

Figure 2: Sources of drinking water.

Table 1: Sources of drinking water and $\mathrm{X}^{2}$ statistic.

\begin{tabular}{llll}
\hline Locations & $\mathrm{X}^{2}$ & $P$-value & Main contributor to $\mathrm{X}^{2}$ \\
\hline Lobethal area (Adelaide Hills) & 140.37 & $<0.0001$ & Mainly rainwater \\
Mount Barker area (Adelaide Hills) & 23.14 & $<0.0001$ & Mainly rainwater \\
Blackwood area (Adelaide foothills) & 22.01 & $<0.0001$ & Mainly rainwater \\
West Lakes area (Adelaide plains) & 280.63 & $<0.0001$ & Mainly rainwater \\
Arndale area (Adelaide plains) & 28.56 & $<0.0001$ & Municipal water and RHRW \\
\hline
\end{tabular}




\subsection{Drinking water preference}

Generally, respondents' choices aligned with municipal water community perception. With the exception of areas where municipal water supplies are limited, many respondents' drinking water choices were driven by municipal water taste rather than its quality. In answering the question 'Why do you prefer RHRW?' the 'yucky factor' associated with municipal water emerged from respondents, who indicated that chlorine and fluoride in drinking water was a source of dissatisfaction regarding drinking water choice. However, there were no respondents identified during the investigation who directly stated that they thought that municipal water chlorination and fluoridation affected their health.

During the investigation, it was common to hear people saying: "although RHRW may contain bugs, it is still better than municipal water". This sentiment was reported all over the metropolitan area, with the sentiment increasing among respondents from the Adelaide foothills towards the Adelaide Hills (see Fig. 3). Of 459 participants, 2 households (the equivalent of $0.4 \%$ respondents) stated that they drank municipal water for health reasons (specifically, that municipal water contains fluoride which is efficient in children dental caries prevention), and 123 (45\%) respondents (out of those 275 respondents who mainly drink municipal water) stated the major reasons as convenience.

Advertising campaigns by water filtration systems suppliers and water purifiers are likely to play a role in consumers thinking that municipal water quality is inferior. In Adelaide, statements such as: "We remove $99.9 \%$ of chemicals and bacteria in your water" are frequently heard in advertising on local radio. This is despite the fact that reticulated municipal water in Adelaide is of very high quality. It should be noted that not all Adelaide households have private RHRW harvesting systems or use RHRW for drinking and cooking. In the model, the probability associated with chi-square values $(P<0.0001)$ shown in Table 2 was lower than the significance level of 0.05 . Thus, the null hypothesis could be rejected for tested parameters. This suggests a plausible relationship between observed drinking water choice, and the place where respondents live in the metropolitan area. In the Adelaide foothills and the Adelaide plains, RHRW for gardening was a major contributor to the chi-square formation whereas 'Have no municipal water' contributed to the chi-square formation only in the Lobethal area, with all parameters equally contributing to the chi-square formation in the Mount Barker area.

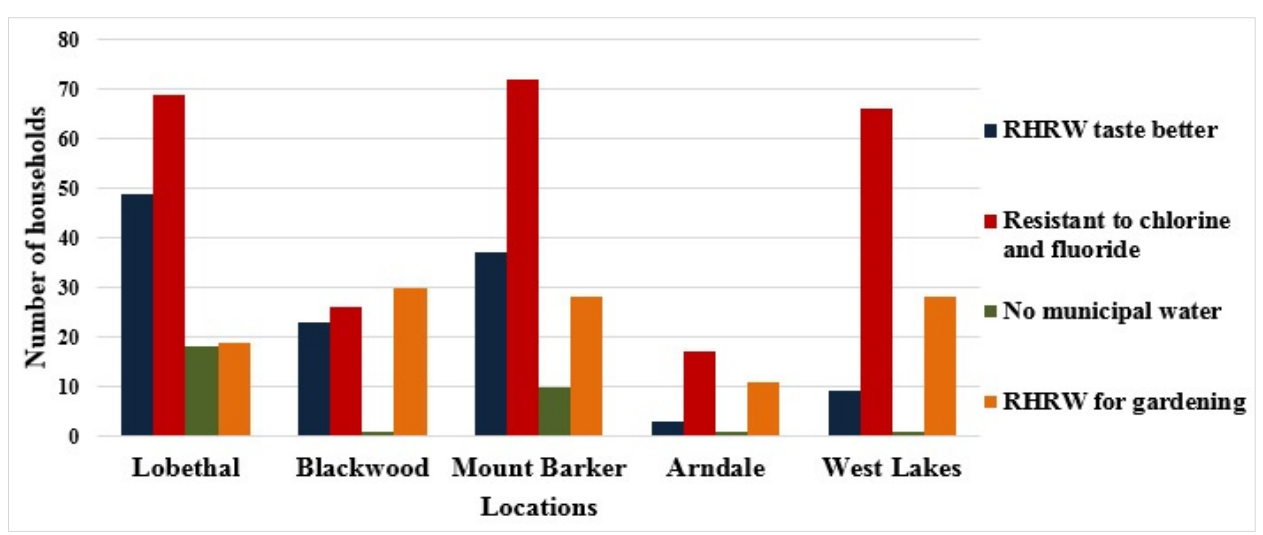

Figure 3: Factors affecting choice of drinking water. 
Table 2: Drinking water choices and $\mathrm{X}^{2}$ statistic.

\begin{tabular}{ll|l|l}
\hline Locations & $\mathrm{X}^{2}$ & $\mathrm{P}$-value & Main contributor to $\mathrm{X}^{2}$ \\
\hline Lobethal area & 25.76 & $<0.0001$ & Have no municipal water \\
\hline Mount Barker area & 1.68 & $<0.0001$ & No difference between parameters \\
\hline Blackwood area & 19.80 & $<0.0001$ & Rainwater for gardening \\
\hline West Lakes area & 7.34 & $<0.0001$ & Rainwater for gardening \\
\hline Arndale area & 21.27 & $<0.0001$ & Rainwater for gardening \\
\hline
\end{tabular}

\subsection{The propensity to filter drinking water}

The investigation observed a higher tendency to use private filtration systems to filter drinking water in the metropolitan area (see Fig. 4). Puratap, an Adelaide domestic water filtration systems supplier established in 1996 [40], sold 280,445 domestic water filtration units to Adelaide households between 1996 and 2016 [41]; the equivalent of approximately half of households in Adelaide [34]. As one household could have more than one water filtration unit and remain recorded as just one unit, it is difficult to estimate the correct number of households using water filtration units. Moreover, the number is not inclusive of water filtration units purchased by households from suppliers other than Puratap, and filters that are imbedded into refrigerators and used to improve drinking water quality.

This study found that private filtration units were applied to both RHRW and municipal water. Unlike municipal water, RHRW is not integrated into SA Water reticulated supply and therefore treatment. So while installation of private filtration systems could be done in households using RHRW for microbiological and toxicological reasons, this cannot be the case for municipal water. In Adelaide, SA Water supplies high quality, safe, reticulated municipal water to communities. Thus, the primary reason for installing filters may be directly linked with water filtration systems suppliers' and water purifiers' campaigns, along with the perception of municipal water. As a result, the study found that the use of private filtration systems on municipal water targeted chlorine and fluorine removal to improve water taste.

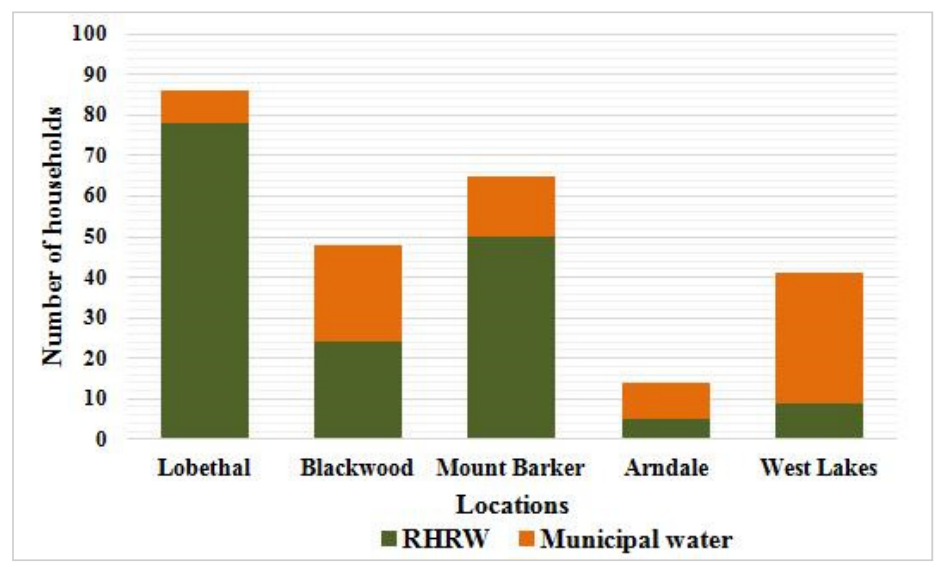

Figure 4: Use of private filtration systems. 
The role of chlorine in water sanitation may have been achieved prior to its removal at the point of consumption. For fluoride however, the chemical is being removed from municipal water before consumption. This practice is counter to Australia drinking water fluoridation policy outlined in the Australian Drinking Water Guidelines (ADWG) [16]. South Australia has no formal legislation on drinking water fluoridation [16]. This study found that the use of private water filtration units on municipal water was higher in the Adelaide foothills and the Adelaide plains. In contrast, the use of private filtration systems was mainly in conjunction with RHRW in the Adelaide Hills and the Adelaide foothills.

In considering chi-square $P$-values $(<0.0001)$ as expressed in the model, the null hypothesis cannot be accepted. For tested parameters, chi-square values ranged from 34.12 in the West Lakes area and 3.83 in Mount Barker area, to 5:00 in the Blackwood area and 5.42 in the Arndale area. This is indicative of householders' wish to improve their drinking water quality on either municipal water or RHRW. Across locations, the main contributor to the chi-square formation was essentially municipal water.

\subsection{Rainwater harvesting and use}

Fig. 5 shows that RHRW used for drinking was highest in the Adelaide Hills, with moderate consumption in the Adelaide foothills. Two factors could explain the results. These are: the observed limited municipal water supply in many small towns and the presence of higher proportion of households having private RHRW harvesting systems in the area and observed resistance to municipal water fluoridation and chlorination. In the Adelaide plains however, the investigation noted that the small number of households having private RHRW harvesting systems used the water primarily for gardening.

In the model, results of chi-square test indicated a relationship between having a private RHRW harvesting system and using RHRW as primary source of drinking water, particularly in the Adelaide Hills and foothills. $P$-values $(<0.0001)$ for tested parameters were lower than the accepted significance level of 0.05 to confirm the rejection of the null hypothesis. Across locations, the study found that RHRW used for gardening was main contributor to chi-square results.

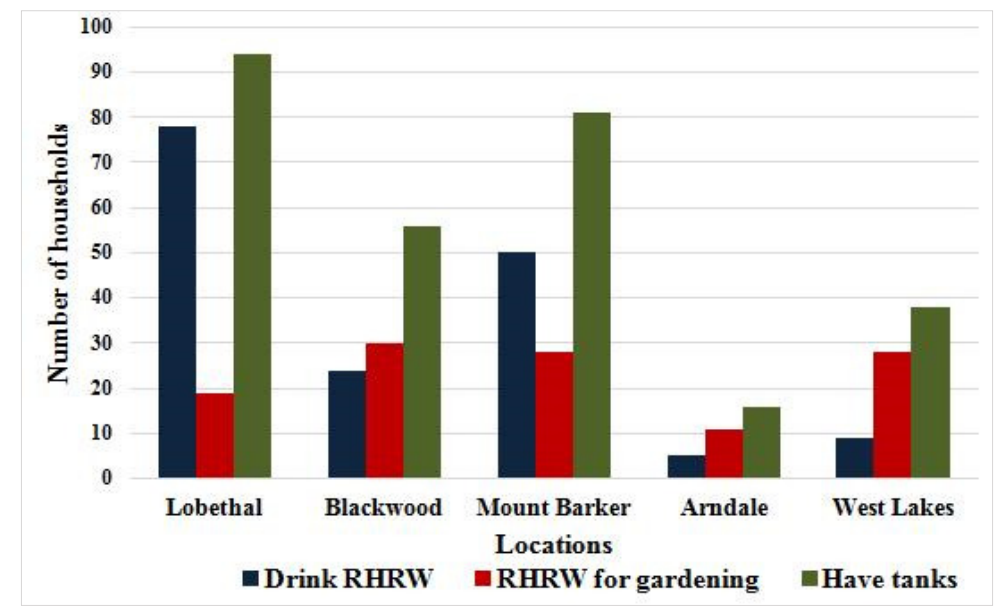

Figure 5: Have tanks and drink rainwater. 


\subsection{Drinking water choice and socio-economic indexes}

In order to understand underlying factors and trends in RHRW consumption within the community, the investigation used suburban postcodes provided by respondents and related socio-economic indexes for areas (SEIFA) to determine households part to the study relative socio-economic indexes. In reference to South Australia SEIFA, respondents were grouped in three categories with the least disadvantaged having a SEIFA greater than 150; with the middle disadvantaged having a SEIFA comprised between 75 and 150 and the most disadvantaged having a SEIFA lower than 75. In the SEIFA indexes scale, the larger the SEIFA, the greater likelihood the area is wealthier.

The study observed a higher proportion of households using both municipal water and RHRW as their primary source of drinking water in the least disadvantaged group. In that category, the majority of respondents indicated that they used private water filtration systems with municipal water to improve water quality. The removal of chlorine and fluoride was main issue of concern. The study found that people in the least disadvantaged group lived in most affluent suburbs of the Adelaide foothills and the Adelaide Hills. Using the same identifiers, the investigation observed a significant proportion of households using bottled water as their primary source of drinking water in the middle and most disadvantaged categories, and majority of respondents were from the Adelaide plains and a few from the Adelaide foothills. In that category, a large fraction of respondents used filtered municipal water for drinking. The proportion of households who used both RHRW and municipal water as their source of drinking water was constant across all sub-groups.

The investigation observed higher opposition to drinking water chlorination and fluoridation in the community. Fig. 6 presents the parameters tested in the model. Chi-square values associated with $P$-values $(P<0.0001)$ were lower than the critical value of 0.05 confirming the rejection of the null hypothesis. In the model, the middle disadvantaged group was the major contributor to the chi-square formation.

The investigation was unable to efficiently untangle the RHRW drinking water factors observed in most affluent Adelaide suburbs. It should be noted that in the least disadvantaged group, people have a range of choices available and given the wealth of people living in the

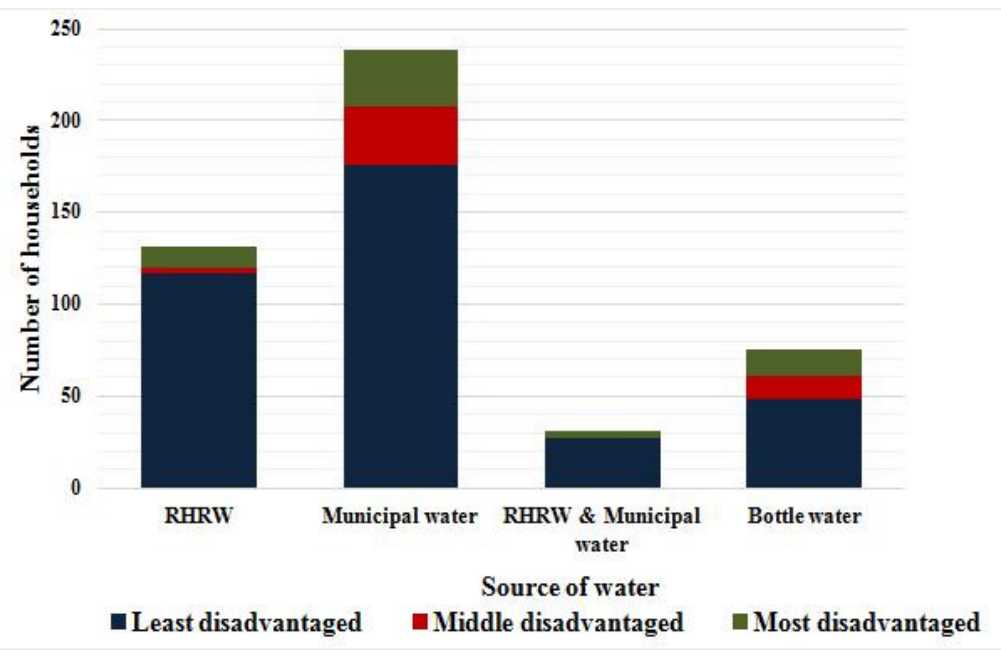

Figure 6: Relative socio-economic indexes and drinking water choice. 
area, households have greater choice in drinking water. Based on respondents SEIFA indexes, people in that group are more likely to be able to afford the equipment required for water filtration, whether it is RHRW or municipal water. This was supported by the study findings that observed a higher proportion of households having private RHRW harvesting systems, and using private water filtration systems to improve the quality of their drinking water in the least disadvantaged group.

\section{CONCLUSION}

The investigation found that in Adelaide, households' drinking water preference was based on the community's perception of municipal water, and the choices of many households were driven by water taste rather than water quality. Opposition to drinking water that has been chlorinated and had fluoride added was high across the community. Municipal water consumption was popular across the metropolitan area, but more popular in the Adelaide plains than in the Adelaide foothills and Adelaide Hills. In contrast, RHRW used as source of drinking water prevailed in the more affluent suburbs of the Adelaide Hills and foothills. Similarly, the consumption of filtered municipal water and bottled water was predominant in the middle and most disadvantaged sub-groups. The investigation observed a higher reliance on RHRW as primary source of drinking water in small towns of the Adelaide Hills. This was a result of both limited supply of municipal water, and observed opposition to drinking fluoridated and chlorinated municipal water in areas where the product was available. With the exception of taste discomfort expressed by most respondents; the investigation recorded no claim of illness as a result of drinking chlorinated and fluoridated municipal water.

\section{ACKNOWLEDGEMENTS}

This investigation was funded by the Australian Government Research Training Program Scholarship (AGRTPS) and supported by the School of the Environment, Environment Health of Flinders University of Adelaide, South Australia.

\section{REFERENCES}

[1] United Nations Children's Fund (UNICEF), Progress on Sanitation and Drinking Water: 2015 Update and MDG Assessment; UNICEF and World Health Organization, WHO Press: Geneva, Switzerland, 2015. Online: http://files.unicef.org/publications/ files/Progress on Sanitation and Drinking Water 2015 Update pdf. Accessed on: 12 Feb. 2017.

[2] United Nations University Institute for Water, Environment \& Health (UNUINWEH): Water Security \& the Global Water Agenda: A UN-Water Analytical Brief. Hamilton, Canada, 2013. Online, http://www.unwater.org/downloads/watersecurity analyticalbrief.pdf. Accessed on: 11 Feb. 2017.

[3] Commonwealth Scientific and Industrial Research Organisation (CSIRO), Australian national outlook 2015 - Insights for food, water and energy - Economic activity, resource use, environmental performance and living standards, 1970-2050, Canberra, Australia, 2015. Online, http://www.csiro.au/nationaloutlook/. Accessed on: 15 Dec. 2016.

[4] Victoria State Government. Government acts to provide Ballarat with water security, Media Release, Melbourne, Australia, 2016. Online, http://www.premier.vic.gov.au/ government-acts-to-provide-ballarat-with-water-security/. Accessed on: 10 Sep. 2016.

[5] SA Water, SA Water strategic plans, 2012-16, Adelaide, Australia, 2016. Online, https://www.sawater.com.au/ data/assets/pdf file/0019/6724/SAWaterStrategicPlan 201216.pdf. Accessed on: 23 Nov. 2016. 
[6] Australian Water Association (AWA), Water security for all Australians, Discussion paper, Sydney, Australia, 2016. Online, https://www.awa.asn.au/documents/Water Security for all Australians.pdf. Accessed on: 10 Jan. 2017.

[7] Jaravani, F.G., Massey, P.D., Judd, J., Allan, J. \& Allan, N., Closing the Gap: the need to consider perceptions about drinking water in rural Aboriginal communities in NSW, Australia. Public Health Research \& Practice, 26(2), pp. 1-5, 2016. DOI: http://dx.doi.org/10.17061/phrp2621616

[8] Alan, J., Personal communication, 19 Jan. 2016. CEO, Walhallow Aboriginal Land \& Environmental Health Officer. Quirindi, NSW, Australia, 2016.

[9] Neuweiler, S, Frustration over poor water quality growing in WA regional communities, 2016. Online, http://www.abc.net.au/news/2016-09-12/water-qualityin-many-wa-regional-towns-still-sub-standard/7836992. Accessed on: 5 Sep. 2016.

[10] Gleick, P.H., The changing water paradigm: a look at twenty-first century water resources development. Water International, 25(1), pp. 127-138, 2000. DOI: http://www.tandfonline.com/doi/abs/10.1080/02508060008686804

[11] Gwenzi, W., Dunjana, N., Pisa, C., Tauro, T. \& Nyamadzawo, G., Water quality and public health risks associated with roof rainwater harvesting systems for potable supply: review and perspectives. Sustainability of Water Quality and Ecology, 6, pp. 107-118, 2015. Online, http://www.sciencedirect.com/science/article/pii/ $\underline{\text { S2212613915000070 }}$

[12] Australian Bureau of Statistics. Environmental Issues: Water use and Conservation, March 2010, Canberra, Australia, 2010 (602.0.55.003). Online, http://www.abs.gov. au/ausstats\%5Cabs@.nsf/0/A568D8D31EA91CCBCA2577DF00155222?Opendocu ment. Accessed on: 17 Oct. 2016.

[13] EPA Victoria, Rainwater use in and around the home, Melbourne, Australia, 2006. Online, http://www.epa.vic.gov.au/ /media/Publications/DSE0603.pdf. Accessed on: 15 Dec. 2016.

[14] Department of Health and Ageing, Guidance on use of rainwater tanks, Canberra, Australia, 2004. Online, http://www.health.gov.au/internet/main/publishing.nsf/ content/D3E8C00F3041304BCA257BF0001C685A/\$File/env rainwater.pdf.

Accessed on: 17 Nov. 2016.

[15] Commonwealth of Australia. Guidance on use of rainwater tanks. enHealth, Canberra, Australia, 2010, (D00042). Online, http://www.health.gov.au/internet/main/ publishing.nsf/content/ohp-enhealth-raintank-cnt.htm. Accessed on: 28 Dec. 2016.

[16] National Health and Medical Research Council (NHMRC), Australian Drinking Water Guidelines 6, 2011, Canberra, Australia, 2016 (Version 3.1). Online: https://www.nhmrc.gov.au/guidelines-publications/eh52. Accessed on: 12 Oct. 2016.

[17] de França Doria M., Factors influencing public perception of drinking water quality. Water Policy, 12(1), pp. 1-9, 2010. Online: http://wp.iwaponline.com/content/12/1/

[18] Australian Government, Testing drinking water for domestic use, 2002. Online: http://www.measurement.gov.au/Services/EnvironmentalTesting/Documents/Testing DrinkingWaterDomesticUse.pdf. Accessed on: 15 Oct. 2016.

[19] Thomas, T., Domestic water supply using rainwater harvesting. Building Research \& Information, 26(2), pp. 94-101, 1998. DOI: http://www.tandfonline.com/doi/abs/ $10.1080 / 096132198370010$

[20] Hurlimann, A. \& Dolnicar, S., Acceptance of water alternatives in Australia - 2009. Water Science and Technology, 61(8), pp. 2137-2142, 2010. Online: http://wst.iwaponline.com/content/61/8/2137 
[21] Calabrese, E.J., Charles, E., Gilbert \& Harris, P., Safe Drinking Water Act, Amendments, Regulations and Standards, Lewis Publishers, Library of Congress, 2nd ed., Michigan, USA, pp. 1-15, 1989. Online: https://searchworks.stanford.edu/view/ 1800739

[22] Victorian Government, Water fluoridation questions and answers, 2009. Online, https://www2.health.vic.gov.au/about/publications/researchandreports/waterfluoridation-questions-and-answers. Accessed on: 5 Jan. 2017.

[23] SA Water, Drinking Water Quality Report, 2013-14, 2014. Online, https://www.sawater.com.au/ data/assets/pdf file/0020/9317/DrinkingWaterQuality Report201314.pdf. Accessed on: 10 Dec. 2016.

[24] Cantor, K.P., Drinking water and cancer. Cancer Causes \& Control, 8(3), pp. 292-308.

[25] Hassinger, E. \& Watson, J., Health Effect of Drinking Water Contaminants, 1998. Online, http://arizona.openrepository.com/arizona/handle/10150/146310

[26] Plewa, M.J, Wagner, E.D., Richardson, S.D., Thruston, A.D., Woo, Y.T. \& McKague, A.B., Chemical and biological characterization of newly discovered iodoacid drinking water disinfection byproducts. Environmental Science \& Technology, 38(18), pp. 4713-4722, 2004. DOI: http://pubs.acs.org/doi/pdf/10.1021/es049971v

[27] Aragón, A., et al., Water fluoridation - a public health hazard. International Journal of Occupational and Environmental Health, 12(1), pp. 88-91, 2006. DOI: http://www.tandfonline.com/doi/abs/10.1179/oeh.2006.12.1.88

[28] Carton, R.J., Review of the 2006 United States National Research Council report: fluoride in drinking water. Fluoride, 39(3), pp. 163-172, 2006. Online, http://media.khi.org/news/documents/2012/07/23/FJ2006_v39_n3_p163-172.pdf

[29] Balog, D.A., Fluoridation of public water systems: valid exercise of state police power or constitutional violation. Pace Envtl L Rev, 14(2), pp. 645-690, 1997. Online, http://digitalcommons.pace.edu/cgi/viewcontent.cgi?article $=1487 \&$ context $=$ pelr

[30] Demos, L.L., Kazda, H., Cicuttini, F.M., Sinclair, M.I. \& Fairley, C.K., Water fluoridation, osteoporosis, fractures-recent developments. Australian Dental Journal, 46(2), pp. 80-87, 2001. DOI: http://onlinelibrary.wiley.com/doi/10.1111/j. $\underline{1834-7819.2001 . t b 00561 . x / p d f}$

[31] Government of South Australia, Summary Offences Act 1953, Adelaide, Australia, 2016. Online, https://www.legislation.sa.gov.au/lz/c/a/summary\%20offences $\%$ 20act\%201953/current/1953.55.un.pdf. Accessed on: 12 Nov. 2016.

[32] National Health Management Resources Corporation (NHMRC), National Statement on Ethical Conduct in Human Research, Canberra, Australia, 2015. Online, https://www.nhmrc.gov.au/guidelines-publications/e72. Accessed on: 13 Nov. 2016.

[33] Australian Bureau of Statistics, National Statistical Service, Sample Size Calculator, Canberra, Australia, 2016. Online, http://www.nss.gov.au/nss/home.NSF/pages/ Sample + Size + Calculator + Stratification + Examples?opendocument. Accessed on: 2 Dec. 2016.

[34] Australian Bureau of Statistics, Household and Family Projections, Australia, 2011 to 2036, Increase in Households, States and Territories, Canberra, Australia, 2015. Online, http://www.abs.gov.au/ausstats/abs@.nsf/mf/3236.0. Accessed on: 19 Dec. 2016.

[35] Australian Bureau of Statistics, State Suburb (SSC) Index of Relative Socio-economic Advantage and Disadvantage, 2011, Canberra, Australia, 2013. Online, http://www.abs.gov.au/AUSSTATS/abs@.nsf/DetailsPage/2033.0.55.0012011?Open Document. Accessed on: 12 Jan. 2016. 
[36] Crampton, A. \& Ragusa, A.T., Exploring perceptions and behaviors about drinking water in Australia and New Zealand: Is it risky to drink water, when and why? Hydrology, 3(1), pp. 1-14, 2016. Online, http://www.mdpi.com/2306-5338/3/1/8/htm

[37] Ward, S., Butler, D. \& Memon, F., A pilot study into attitudes towards and perceptions of rainwater harvesting in the UK. BHS $10^{\text {th }}$ National Hydrology Symposium, Centre for Water Systems, University of Exeter, Exeter, UK, 2008. Online, https://ore.exeter.ac.uk/repository/handle/10036/4251

[38] de França Doria, M., Pidgeon, N. \& Hunter, P.R., Perceptions of drinking water quality and risk and its effect on behaviour: A cross-national study. Science of the Total Environment, 407(21), pp. 5455 -5464, 2009. Online, http://www.sciencedirect.com/ science/article/pii/S0048969709006111

[39] Marks, J., Martin, B. \& Zadoroznyj, M., Acceptance of water recycling in Australia: national baseline data. Water, 33(2), pp. 151-157, 2006. DOI: http://citeseerx.ist.psu. edu/viewdoc/download?doi=10.1.1.1019.2031\&rep=rep1\&type $=$ pdf

[40] Puratap, What is trending right now? Australian made, Adelaide, Australia, 2016. Online, https://www.puratap.com.au/about-us. Accessed on: 18 Dec. 2006.

[41] Jana, C., Personal communication, 2 Jun. 2016, Administrative Officer at Puratap Pty Ltd, Head Office, Adelaide, Australia, 2016. 